\title{
Is a Sun Smart Policy needed to Protect Athletes?
}

\section{Spanoudaki S*}

Department of Sports Medicine \& Biology of Physical Activity, Faculty of Physical Education and Sports Science, National \& Kapodistrian University of Athens, Greece

We spend a lot of effort trying to protect our athletes from overtraining, immunosuppression, illness, dehydration during training, insufficient nutrition status, injuries etc. We ask our athletes to be thoroughly examined by physicians in order to avoid harmful consequences to their health, such as sudden cardiac death.

Do we protect our athletes from sun exposure effects? Exposure mainly occurs during outdoor occupational or recreational activities. Solar exposure is beneficial, since it is responsible for the synthesis of vitamin $\mathrm{D}$ [1]. On the other hand, skin cancer is caused by overexposure to ultraviolet radiation (UVR) from the sun. This radiation penetrates the skin and damages the living cells [2]. The incident rate of melanoma (form of skin cancer) has increased in the last decade more than any other type of preventable cancers [3].

Skin cancer is mainly a disease that affects Caucasians, who have light skin and eyes. Excessive sun exposure during the first twenty years of life or a tendency to burn rather than tan when exposed to the sun, increases significantly the risk of skin cancer [4]. Apart from that, a number of other factors, such as reduced capacity to repair UV induced DNA damage, immunosuppression by UV radiation increase the risk of skin cancer [5]. However, UV exposure is considered to be the most important risk factor [6]. Much of the damage occurs during childhood and adolescence [7-8].

Many countries have developed sun protection education programs [9-11]. These programs try to establish safe and healthy habits for children concerning their behavior towards the sun. Shortly, they learn to avoid exposure to UVR between the hours of $10 \mathrm{am}-3 \mathrm{pm}$, to utilize outdoor shade, use sunscreen and protective clothes, wear hats and sun glasses [10]. Sun protection policy usually is taught in schools because sun exposure during childhood accounts for $80 \%$ of total lifetime exposure [12]. In addition, children receive three times higher UV dose versus adults [13].

Few studies have examined sun protection behaviors during physical activity. Serano et al. [14], mentioned that mountaineers received higher dose of UV exposure compared to tennis players and runners, probably due to the time that training takes place. Others, examined cyclists and triathletes during Tour de Suisse and Ironman Triathlon World Championships accordingly, and found that UV exposure exceeded the recommended limits of the International Commission for Nonionizing radiation Protection [15,16]. Furthermore, Lawler et al. [17], examined four sports (field hockey, soccer, tennis and surf) in young adults. They found that surfers were more likely to incur a sunburn versus athletes of the other three sports. All the participants used sunscreen, while hats and sunglasses was either not chosen or regulations and safety issues prevented athletes from using them. In addition, hats and long sleeve pants make the competition or training difficult when the weather is too hot [18]. Therefore, there is a need for different rules and norms, uniforms, clothing times, place of competition, according to the type of physical activity.

Supervised recreational and Sports programs are conducted mostly or entirely outdoors, therefore trainers should inform their athletes about sun protection and overexposure consequences, in order to create sun protection habits.

Even if school programs and parents inform students about sun protection, their attitude towards sun policy becomes worse, as they grow older [19]. So, trainers should remind them the safety rules and become an example by adopting such behavior. Also, trainers should be cautious when their athletes exercise in highly reflective surfaces, such as, water, sand and snow, since these surfaces can increase UV radiation exposure by approximately $90 \%$ [20].

Although, administering a sun protection policy for athletes practicing outdoor is difficult, we should consider that applying a few basic rules such as wearing a hat, apply a water proof sunscreen $30+$ and wearing protective clothes, will significantly reduce the possibility of skin cancer in the future.

\section{References}

1. Norval M, Cullen AP, De Gruijl FR, Longstreth J, Takizawa Y, et al. (2007) The effects of human health from statosperic ozone depletion and its interactions with climate change. Photochem Photobiol Sci 6: 232-251.

2. Marks R, Jolley D, Lectsas S, Foley P (1990) The role of childhood exposure to sunlight in the development of solar keratosis and non- melanocytic skin cancer. Med J Aust 152: 62-66.

3. Ries LAG, Eisner MP, Kosary CL, Hankey BF, Miller BA, et al. (2003) Seer Cancer Statistics Review, 1975-2000. National Cancer Institute.

4. Ramirez CC, Federman DG, Kirsner RS (2005) Skin cancer as an occupationa disease: the effect of ultraviolet and other forms of radiation. Int $\mathrm{J}$ Dermatol 44: $95-100$.

5. Ullrich SE (2002) Photoimmune suppression and photocarcinogenesis. Fron Biosci 7: d684-d703.

6. Armstrong BK, Kricker A (2001) The epidemiology of UV induced skin cancer. $J$ Photochem Photobiol B 63: 8-18.

7. Gilchrest BA, Eller MS, Geller AC, Yaar M (1999) The pathogenesis of melanoma induced by ultraviolet radiation. N Engl J Med 340: 1341-1348.

8. Weinstock MA, Coldritz GA, Willett WC, Stampfer MJ, Bronstein BR, et al (1989) Nonfamilial cutaneous melanoma incidence in women associated with sun exposure before 20 years of age. Pediatrics 84: 199-204.

9. Li J, Uter W, Pfahlberg A, Gefeller O (2012) A comparison of patterns of sun protection during beach holidays and everyday outdoor activities in a population sample of young German children. Br J Dermatol 166: 803-810.

10. Geller AC, Rutsch L, Kenausis K, Selzer P, Zhang Z (2003) Can an hour or two of sun protection education keep the sunburn away? Evaluation of the Environmental Protection Agency's Sunwise School Program. Environ Health 2:13.

11. Buller DB, Geller AC, Cantor M, Buller MK, Rosseel K, et al. (2002) Sun protection policies and environmental features in US elementary schools. Arch Dermatol 138: 771-774.

12. Preston DS, Stern RS (1992) Nonmelanoma cancers of the skin. N Engl J Med 327: 1649-1662.

*Corresponding author: Sofia S. Spanoudaki, 1, Valtetsiou St, Vrilissia 15235 41 Ethnikis Antistasis, Dafni Athens Greece, Tel: 0030 - 2108103282; Fax: 0030 2109708367; E-mail: sspanoud@yahoo.gr

Received July 11, 2012; Accepted September 04, 2012; Published September 07, 2012

Citation: Spanoudaki S (2012) Is a Sun Smart Policy needed to Protect Athletes? J Sports Med Doping Stud 2:115. doi:10.4172/2161-0673.1000115

Copyright: ( 2012 Spanoudaki S. This is an open-access article distributed under the terms of the Creative Commons Attribution License, which permits unrestricted use, distribution, and reproduction in any medium, provided the original author and source are credited. 
13. Berneburg M, Surber C (2009) Children and sun protection. Br J Dermatol 161: 33-39.

14. Serrano MA, Canada J, Moreno JC (2011) Ultraviolet exposure for different outdoor sports in Valencia, Spain. Photodermatol Photoimmunol Photomed 27: 311-317.

15. Moehrle M, Heinrich L, Schmid A, Garbe C (2000) Extreme UV exposure of professional cyclists. Dermatology 201: 44-45.

16. Moehrle M (2001) Ultraviolet exposure in the Ironman triathlon. Med Sci Sports Exerc 33: 1385-1386

17. Lawler S, Spathonis K, Eakin E, Gallois C, Leslie E, et al. (2007) Sun exposure and sun protection behaviours among young adult sport competitors. Aust N Z J Public Health 31: 230-234.

18. Hill D, Rassaby J, Gardner G (1984) Determinants of intentions to take precautions against skin cancer. Community Health Stud 8: 33-44.

19. Geller AC, Colditz G, Oliveria S, Emmons K, Jorgensen C, et al. (2002) Use of sunscreen, sunburning rates and tanning bed use among more than 10000 US children and adolescents. Pediatrics 109: 1009-1014.

20. Dadlani C, Orlow SJ (2008) Planning for a brighter future: a review of sun protection and barriers to behavioral change in children and adolescents. Dermatol Online J 14: 1 